University for Business and Technology in Kosovo

UBT Knowledge Center

Nov 7th, 9:00 AM - 5:00 PM

\title{
Transitional justice in state-building processes in Kosovo - social constructivism perspective
}

Dorota Heidrich

University of Warsaw, d.heidrich@uw.edu.pl

Follow this and additional works at: https://knowledgecenter.ubt-uni.net/conference

Part of the Political Science Commons

\section{Recommended Citation}

Heidrich, Dorota, "Transitional justice in state-building processes in Kosovo - social constructivism perspective" (2015). UBT International Conference. 9.

https://knowledgecenter.ubt-uni.net/conference/2015/all-events/9

This Event is brought to you for free and open access by the Publication and Journals at UBT Knowledge Center. It has been accepted for inclusion in UBT International Conference by an authorized administrator of UBT Knowledge Center. For more information, please contact knowledge.center@ubt-uni.net. 


\title{
Transitional justice in state-building processes in Kosovo - social constructivism perspective
}

\author{
Dorota Heidrich \\ Institute of International Relations, University of Warsaw \\ d.heidrich@uw.edu.pl
}

\begin{abstract}
This paper presents preliminary remarks for the research project on Transitional justice in Kosovo. Building a state, recovering from the past. The main research questions concern how and why transitional justice efforts in Kosovo have been constructed and implemented. The project will involve discussion about transitional justice (TJ) as a concept; the background of Kosovo conflict and how it internalized international norms and standards connected to transition and peace-building efforts. Social constructivism's relevance as IR will be tested.
\end{abstract}

Keywords: transitional justice, Kosovo, norm internalization

\section{Introductory remarks}

Since the armed conflict in Kosovo and crimes committed on its territory before the outbreak of organized violence, during the fighting and in its aftermath Kosovo has been on a dy namic path of at first - recovery and - then on - state building process which led to declaration of independence in 2008. It also required constant effort to balance between stability (peace) and justice, facing past violations of human rights by applying various transitional justice mechanisms.

The present paper presents preliminary findings for the project titled Transitional justice in statebuilding processes in Kosovo - social constructivism perspective, which is being realized by my self as representative of the Institute of International Relations of the University of Warsaw and the University for Business and Technology in Prishtina.

The primary interest of the project rests in the process of construction, introduction and implementation of transitional justice measures in Kosovo and its impact on the process of building state.

Four research questions will be posed:

1. How did Kosovo design its transitional justice efforts; what was the process of TJ norms and standards internalization like?

2. To what extent have TJ norms and standards constitute the state identity of Kosovo?

3. Can the analysis of the Kosovo case lead to some general regularities/patterns/models? Answers to these questions will allow to define the ontological scope of the project and to verify its principle thesis, which claims that:

The process of internalization of TJ norms and standards in Kosovo could did take place, because of a strong belief that bringing justice and reconciliation were significant factors that would strengthen Kosovo statehood and allow Kosovo to uphold its status in international relations.

Having defined the ontological scope of the research, it is necessary to choose the right theoretical model that will help explain the significance of TJ norms and standards in state-building processes in Kosovo. Social constructivism, and within it - especially Alexander Wendt's social theory of international relations, will be applied as theoretical framework for the research. Analytical appropriateness of this theoretical model is determined by its ontological and epistemological assumptions. These, on the one had, point to the nonmaterial factors (not excluding the influence of material ones) in the process of construction of states' identity and interests and, on the other hand, emphasize the significance of international structure/system in this very process. Wendt's theory is therefore useful in researching the multidimensional problem of state-building in Kosovo. 
. Rationalist explanations in the form of neorealism or institutional liberalism would not be helpful paradigms here, as they do not consider, besides material factors, ideational factors like culture, identity and the role of norms in international relations which we think are of great significance to understanding why and how Kosovo decided to abide by standards that were regarded to be appropriate measures to deal with the past and to lead the state-building process to a successful end. The Kosovo case-study research will be primarily empirical, with textual analy ses of documents and a case study. The latter will be based on scholarly literature and knowledge gained from semi structured interviews conducted by the author with officials and other individuals in Kosovo and in governmental and non-governmental organizations, mainly in Brussels. It will be finalized by a monograph published first in Poland (in Polish) and later on in English, too.

What needs emphasis is the fact that neither Kosovo, nor transitional justice have so far gained enough attention in the Polish literature. That makes the project topic original and valuable for Polish readers. Sources in foreign languages on both topics are abundant, though. The book will be structured as follows: 1). Introduction of the concept of transitional justice, together with theory of transitional justice; 2) transitional justice from IR theory perspective: why do states decide to apply transitional justice measures - constructivist perspective?; 3) background of ethnic conflict in Kosovo with emphasis on mass violations of human rights; the aftermath of the conflict and efforts on transitional and state - building processes; 4) transitional justice in state-building processes in Kosovo - the relevance of social constructivism approach. This presentation elaborates on the first and second part.

\section{Transitional justice as a concept in international re lations studies}

Introduction of transitional justice measures is regarded to be an important part of state-building and political transition efforts. For the sake of the project, transitional justice will be understood as a set of judicial and non-judicial approaches that communities may use in order to deal with the legacy of massive and systematic human rights violations. Such violations did take place on the territory of today's Kosovo, as they did in other parts of the Former Yugoslavia in the process of its split. The idea that similar abuses must be dealt with has been present in both practice and theoretical analy ses at least from the 1990s. The concept of transitional justice appeared in reference to political transitions in Latin America and Easter Europe in late 1980s and right after the collapse of the Eastern Block and the end of the Cold War confrontation. The central question then was how the successor regime should tackle the violent past. Since the period from 1989 and onwards has been packed with regime changes and political transformations throughout the continents, transitional justice was becoming more and more a popular idea. As Christine Bell (Bell, 2009, pp. 7-8) notes, the term 'transitional justice' was first used in 1995 by Neil Kritz in a study titled Transitional Justice: How Emerging Democracies Recon with Former Regimes. Kritz proposed a meticulous analy sis of the instruments of TJ (Kritz, 1995). Throughout the 1990s the concept was becoming more and more popular as practice was abundant in experiences from transition countries that made different decisions on how to deal with the past. The activities of the South African Truth and Reconciliation Commission, the creation of the first after the Second World War criminal tribunals for the Former Yugoslavia and for Rwanda (and later of the first ever permanent International Criminal Court, as well as internationalized jurisdictions) fuelled interest in transitional justice.

First seen as a filed purely for legal scholars, transitional justice has now been regarded as a concept which requires a much broader analysis by lawyers, political scientists, IR scholars but also such disciplines as anthropology, cultural studies, development studies, economics, education, ethics, history, philosophy, psychology, sociology and theology (Bell, 2009, p. 9). The gradual widening of the range of disciplines interested in transitional justice results from broadening of the concept itself; it has moved from merely dealing with past human rights abuses to the concept of mechanisms of transition understood in the broadest possible way. One may look at transitional justice as Ruti Teitel proposes, saying that " $[\mathrm{t}]$ he problem of transitional justice arises within the distinctive context of transition - a shift in political orders" (Teitel, 2000, p. 5).

For the purpose of the analysis, the term "transitional justice" will be applied only to countries undergoing transition after a conflict or authoritarian rule, not considering states that after the prevalence of years of stabile democratic system, began coming to terms with past wrongdoings from decades before. The intention is not to play down such effort but it is argued that, from the ontological and methodological point of view, it is inappropriate to include the latter. Such examples include for 
instance Canadian or Australian policies of asking forgiveness to the indigenous peoples for the crimes committed against them or processes taking place in Spain the aim of which is to discover (or sometimes rediscover) truth about the crimes committed during the rule of general Franco's junta. The challenge here is whether one should apply a specific time limit to separate cases of countries undergoing political transition from these that reopen the pages of the long ago closed history books. One of the most troubling examples would be Poland where, depending on political circumstances, vetting in the form of lustration keeps coming back and state institutions change track of communism era crimes documenting depending on the direction of political breeze. Transitional justice mechanisms may sometimes be used as a political weapon; that problem will be tackled throughout the project. The German case is another interesting one. We may ask ourselves whether Germany's efforts to come to terms with the Nazi past and with the events that were taking place after the Potsdam Treaty was signed (forcible displacement of the German population from territories given to Poland by means of the Treaty) still represent a form of continuation of transitional justice efforts. For example trials against individuals responsible for crimes committed during the Second World War before national courts are surely about dealing with past abuses. Being aware of these dilemmas, we consciously exclude such cases as Poland and Germany from transitional justice countries definition for reasons presented above.

Transitional justice has been central issue for governmental and non-governmental institutions: the beginning of the new Millenium brought the conception of the International Centre for Transitional Justice. In 2007 the first issue of a scholarly journal fully devoted to transitional justice - the International Journal of Transitional Justice - saw light. Governmental international organizations began acknowledging the term and adopting it to their jargons. The United Nations (UN) Secretary General published in 2004 a Report on the Rule of Law and Transitional Justice in Conflict and PostConflict Societies $\square$ (United Nations, 2004) and since 2010 the UN and its structural bodies are to act in the filed of transitional justice process accordingly to Guidance Note of the Secretary - General on the United Nations Approach to Transitional Justice (United Nations, 2010). The document provides for "the guiding principles and framework for United Nations approach to transitional justice processes and mechanisms" (United Nations, 2010, p. 2). Transitional justice processes and mechanisms are regarded as a ,critical component of the United Nations framework for strengthening the rule of law" (United Nations, 2010, p. 2).

Despite the growing popularity of the concept of transitional justice, there is little agreement among scholars on what transitional justice (as a concept) actually is. Some are of the opinion that it has already become a ,filed of scholarship, connected to a field of practice”, others rather tend to be more prudent saying that TJ merely ,is a label or cloak" (Bell, p. 5-6). Even though there is little doubt that justice and reconciliation by implementing transitional justice mechanism is an indispensible element of state-building, some scholars are highly critical of how these mechanisms are implemented and what their effectiveness is. As Jelena Subotić has put it: "transitional justice (...) is quickly becoming an international norm, a standard of proper state behaviour, violation of which will be internationally sanctioned. Yet the way this new international norm has played itself out in the real politics of countries that have adopted it has departed greatly from international expectations" (Subotić, 2009). Her remarks must not be ignored or regarded as unfounded. The international pressure on states that undergo transition processes to include some kind of transitional justice options sometimes is regarded as a stick (of the stick and carrot method of influence). Once they comply and show readiness to abide by international standards, deals are done without a frown. In the case of Kosovo, like in Croatia or Serbia, the path to association with and accession to the European Union is so strong a desire that these states were/are ready to do a lot to fulfil the requirements. This, in the case of a huge societal project as reconciliation, may threat that standards imposed by the international community are internalized only because of coercion or self - interest, to use the hypotheses of internalization of cultures of anarchy proposed by Alexander Wendt (Wendt, 1999). And that is not what one would expect as the result of transitional justice measures implementation. What we would much prefer is full internalization of norms and standards out of the belief in their legitimacy, not out of coercion, as otherwise, should coercion or belief in self - interest disappear, the norm and standard is left behind with no remorse. Transitional justice and reconciliation is by no means a linear process. However, reconciliation may be regarded as successful only if past wrongdoing does not reappear and the state may thrive. But for that societies must learn about their past because only then will they become aware of what is right and what is not. 


\section{Transitional justice mechanis ms creation and implementation - social constructivism approach}

As indicated above, constructivism will serve as the theoretical base for the analy sis of the research items. Besides what has already been said, ie. That constructivism allows consider in the analysis ideational factors that shape material ones, the level of analy sis offered by this theory (if we regard constructivism to be theory, rather than, as suggested by eg. Knud Erik Jørgensen (Jørgensen, p. 20) not a substantive theory that can be combined with all substantive theoretical traditions) best fit the endeavour to research the process of transitional justice norms internalization and implementation in Kosovo. It also allows to see a perennial of distinction and/or relation between actor (agent) and structure. One of the hy pothesis of the research will argue that Kosovo (as an actor/agent) was strongly influenced by the structure in which it operates (international community of states, both these that recognize Kosovo and these that refuse to accept its existence as a sovereign entity), which allows to see one more reason to apply constructivist theory.

The monograph will offer a concise overview of constructivism witch will be omitted in the course of this analysis due to limited space of the presentation. However, we would like to stress that

predominantly the analy sis will draw upon the work of Alexander Wendt ${ }^{117}$ (Wendt, 1999) and his idea of internalization of norms of cultures of anarchy and Martha Finnemore's (Finnemore, 1996; Finnemore and Sikkink, 1998; Barnett, Finnemore, 2005)) constructivist system analysis which concentrates on international norms diffusion and on how these norms influence states' identities and interests. Wendt and Finnemore emphasize the predominant role of the international system's influence on states identities (the system with its own culture constructs the agents but - to turn that around - the agents influence the system by their common beliefs, patterns of behaviour, etc.). However, it will also be valuable to use apply the findings made by Thomas Risse et al. (Risse, Ropp, Sikkink,1999) and Peter Katzenstein (Katzenstein, 1996) that stress the importance of national environment in norms internalization.

Last but not least, I would lie to take this opportunity to express my deep gratitude to the authorities of both Institute of International Relations of the University of Warsaw and University for Bussiness and Technology in Prishtina for offering me the opportunity to move forward with the project and for all their support, both in the form of material and non-material means. This project will broaden the scope of cooperation (dating back to 2013 introduction of joint BA and MA in IR taught in in Prishtina) between University of Business and technology and the University of Warsaw. It will be the first research project initiative in the frame of cooperation of the two universities.

\footnotetext{
117 Through the analysis of discursive interactions between Kosovo and these members of the international society (the definition of international society taken from Hedley Bull) that recognize the statehood of Kosovo we may determine that Kosovo now forms part of the Kantian anarchical culture with internalization of that culture approaching the third cycle hypothesis (constructivist) of norm internalization. However Kosovo's actions and identity is also influenced by specific relations with Serbia which rather directs us to witness the Lockean type of anarchy, where states see each other as rivals, where conflict is not excluded, however states tend to avoid multiplication of their military capabilities for the very sake of it, as in the Hobbesian culture. We argue that the pressure from Kantian culture of anarchy made Kosovo and Serbia internalize norms and standards that they apply in their mutual relations but only out of coercion and self-interest (first and second cycle hy pothesis on culture internalization.
} 


\section{References}

1. Barnett, M., Finnemore, M.. Rules for the World: International Organizations in Global Politics. Ithaca: Cornell University Press, 2005

2. Bell, Ch. "Transitional Justice, Interdiscip linarity and the State of the "Field" or "Non-Field," International Journal of Transitional Justice 3(1) (2009)

3. Finnemore, M. National Interests in International Society. Ithaka: Cornell University Press, 1996

4. Finnemore, M., Sikkink, K., International Norm Dynamics and Political Change, International Organization 52 (4) (Autumn, 1998)

5. Jørgensen, K.E. International Relations Theory: A New Introduction. Ithaca: Cornell University Press, 2010

6. Katzenstein, P. Cultural Norms and National Security. Ithaca: Cornell University Press, 1996

7. Kritz, N.J. Transitional Justice: How Emerging Democracies Reckon with Former Regimes. Washington, DC: United States Institute of Peace Press, 1995

8. Risse, T., Ropp S. C., Sikkink, K. (eds.). The Power of Human Rights: International Norms and Domestic Change. Cambridge: Cambridge University Press, 1999

9. Subotić, J. Hijacked Justice: Dealing With the Past in the Balkans. Ithaca: Cornell University Press, 2009

10. Teitel, R.G. Transitional Justice. Oxford: Oxford University Press, 2000

11. United Nations Secretary-General. Guidance Note on the United Nations Approach to Transitional Justice. United Nations, 2010

12. United Nations Secretary-General. Report on the Rule of Law and Transitional Justice in Conflict and Post- Conflict Societies. United Nations, 2004

13. Wendt, A. Social Theory of International Politics. Cambridge: Cambridge University Press, 1999 